\title{
Pendaftaran Peralihan Hak Atas Tanah Karena Jual Beli
}

\author{
Nuridin ${ }^{1}$, Muhammad Wildan², \\ Universitas Pancasakti Tegal \\ Masuk: 14 Juli 2020; Diterima: 30 November 2020; Terbit: 30 November 2020. \\ DOI: $10.24905 /$ diktum.v8i2.91
}

\begin{abstract}
Buying and selling is something that is already familiar to us. Buying and selling in this case the sale and purchase of land rights often occurs in the community, but in its implementation the community has not been too understanding in terms of land registration procedures due to legal acts of sale and purchase. The lack of understanding from the community resulted in disputes in the future such as the rise of disputes over land rights resulting from the transfer of rights to land that had not yet been registered. This writing uses a normative juridical research method, where this study refers to the provisions of applicable laws and regulations. The results of the study show that legal actions through buying and selling must be officially registered with the local Land Office. The purpose of registering the transfer of land rights is to obtain legal guarantees for the parties regarding ownership of the land rights. So that there is a need for further understanding of the importance of registration of land rights due to buying and selling.
\end{abstract}

Keyword: Land Registration, Transition of Land Rights, Sale and purchase of land

\begin{abstract}
Abstrak
Jual beli adalah sesuatu yang sudah akrab bagi kegiatan perekonomian, aktivitas jual beli dapat terkait dengan benda apapun tak terkecuali tanah. Jual beli dalam hal ini adalah terkait dengan jual beli hak atas tanah yang kerap terjadi di masyarakat, namun dalam pelaksanaannya masyarakat belum terlalu memahami dalam hal prosedur pendaftaran tanah akibat tindakan hukum jual beli yang dilakukan. Kurangnya pemahaman dari masyarakat mengakibatkan perselisihan di masa depan seperti maraknya sengketa hak atas tanah hasil pengalihan hak atas tanah yang belum terdaftar. Tulisan ini menggunakan metode penelitian yuridis normatif, di mana penelitian ini mengacu pada ketentuan peraturan perundang-undangan yang berlaku. Hasil penelitian menunjukkan bahwa tindakan hukum melalui jual beli harus terdaftar secara resmi di Kantor Pertanahan setempat. Tujuan mendaftarkan pengalihan hak atas tanah adalah untuk mendapatkan jaminan hukum bagi para pihak mengenai kepemilikan hak atas tanah tersebut. Sehingga perlu adanya pemahaman lebih lanjut tentang pentingnya pendaftaran hak atas tanah akibat jual beli.
\end{abstract}

Kata Kunci: Pendaftaran Tanah, Transisi Hak Atas Tanah, Penjualan dan Pembelian Tanah

\footnotetext{
${ }^{1}$ Coresponding author: nuridin@gmail.com
} 


\section{A. Pendahuluan}

Tanah mempunyai hubungan yg sangat erat dengan kehidupan manusia. Tanah merupakan tempat dimana manusia tinggal, tempat dimana manusia beraktifitas, bahkan ketika mati pun manusia akan kembali ke tanah. Berbicara menegenai tanah juga tidak terlepas dari pada pemilikan hak atas tanah tersebut. Dalam Pasal 19 ayat (1) Undang - Undang Nomor 5 Tahun 1960 atau biasa kita kenal dengan Undang - Undang Pokok Agraria (UUPA) menyebutkan bahwa untuk menjamin kepastian hukum oleh Pemerintah diadakan pendaftaran tanah di seluruh wilayah Republik Indonesia menurut ketentuan ketentuan yang diatur dengan Peraturan Pemerintah. (Santoso C. M., 2015)

Berdasarkan pasal 1 ayat (1) Peraturan Pemerintah nomor 24 Tahun 1997 tentang Pendaftaran Tanah, bahwa Pendaftaran tanah adalah rangkaian kegiatan yang dilakukan oleh pemerintah secara terus - menerus, berkesinambungan dan teratur, meliputi pengumpulan, pengolahan, pembukuan, dan penyajian serta pemeliharaan data fisik dan data yuridis, dalam bentuk peta dan daftar, mengenai bidang - bidang tanah dan saturan satuan rumah susun, termasuk pemberian surat tanda bukti haknya bagi bidang - bidang tanah yang sudah ada haknya dan hak milik atas satuan rumah susun serta hak - hak tertentu yang membebaninya. (Marhel, 2017)

Dalam kaitannya dengan pendaftaran tanah, berarti perlu juga dilakukan pendaftaran tanah terhadap perbuatan hukum peralihan hak atas tanah yang dalam hal ini adalah peralihan hak atas tanah karena jual beli. Pendaftaran peralihan hak atas tanah ini merupakan salah satu bagian dari pelaksanaan pemeliharaan data pendaftaran tanah, yaitu yang meliputi pendaftaran peralihan hak dan pembebanan hak, dan pendaftaran perubahan data pendaftaran tanah.

Pendaftaran peralihan hak hak atas tanah karena perbuatan hukum jual beli harus segera mungkin dilakukan dengan maksud untuk menjamin 
kepastian hukum bagi para pihak, serta demi terselenggaranya tertib administrasi pertanahan. Jadi tidak segera di daftarkan maka akan muncul kerancuan kepemilikan hak atas tanah. Banyak terjadi permasalahan permasalahan tentang kepemilikan hak atas tanah yang disebabkan dari peralihan hak atas tanah yang tidak segera di daftarkan, apalagi jika peralihan hakatas tanah tersebut hanya dilakukan di bawah tangan.

Berangkat dari latar belakang diatas maka dapat dikaji persoalan hokum agrarian terkait dengan bagaimana prosedur pelaksanaan jual beli menurut Peraturan Pemerintah Nomor 24 Tahun 1997, dan bagaimana pelaksanaan pendaftaran peralihan hak atas tanah karena jual beli menurut Peraturan Pemerintah Nomor 24 Tahun 1997.

\section{B. Metode Penelitian}

Penelitian ini menggunakan pendekatan yuridis normatif. Yakni penelitian hukum yang menkaji norma hukum positif. (Pratama, 2020) Dimana pada penelitian ini akan mengkaji bagaimana pendaftaran tanah karena jual beli sebagaimana diatur dalam Peraturan Pemerintah Nomor 24 Tahun 1997. Sumber data yang di gunakan ada 2 sumber data, yaitu sumber data primer dan sekunder. Sumber data perimer yaitu berasal dari hasil wawancara lapangan dengan subyek hukum pendaftaran tanah di Kantor Agraria, sedangkan sumber data sekunder yang berisi peraturan perundang-undangan dan artikel hukum dalam jurnal ilmiah. Wawancara penelitian ditujukan untuk mendapatkan informasi dari satu sisi saja. Wawancara penelitian lebih dari sekedar percakapan dan berkisar dari informal ke formal. Walaupun semua percakapan mempunyai aturan peralihan tertentu atau kendali dari satu atau partisipan yang lain,aturan pada wawancara penelitian lebih ketat. (Rachmawati, 2007) Sumber bahan hukum primer berasal dari Peraturan Pemerintah Nomor 24 tahun 1997 tentang Pendaftaran Tanahdan tentunya Undang - Undang Nomor 5 Tahun 1960 tentang Peraturan Dasar Pokok - Pokok Agraria sebagai sumber 
dasar hukumnya. Data dianalisa secara kualitatif dengan menjelaskan bagian khusus ke umum agar memudahkan penjelasan terkait proses pendaftaran tanah karena jual beli.

\section{Pembahasan}

1. Prosedur Pelaksanaan Jual Beli Menurut Peraturan Pemerintah Nomor 24 Tahun 1997

Pendaftaran tanah meliputi dua hal pokok yaitu, pendaftaran tanah untuk pertama kali dan pemeliharaan data pendaftaran tanah. Pendaftaran untuk pertama kali menurut PP No.24 tahun 1997 adalah kegiatan pendaftaran tanah yang dilakukan terhadap objek pendaftaran tanah yang belum didaftar berdasarkan Peraturan Pemerintah Nomor 10 Tahun 1961 tentang Pendaftaran Tanah. dalam pendaftaran tanah pertama kali meliputi pendaftaran tanah secara sistematis (pendaftaran tanah serentak) dan pendaftaran tanah secara sporadis (pendaftaran tanah individu).

Di zaman informasi ini maka Kantor Pertanahan sebagai kantor digaris depan haruslah memelihara dengan baik setiap informasi yang diperlukan untuk suatu bidang tanah, baik untuk pemerintah sendiri sehingga dapat merencanakan pembangunan Negara dan juga bagi masyarakat sendiri. Informasi itu penting untuk dapat memutuskan suatu yang diperlukan dimana terlibat tanah, yaitu data fisik dan yuridisnya, termasuk untuk satuan rumah susun, informasi tersebut bersifat terbuka untuk umum artinya dapat diberikan informasi apa saja yang diperlukan atas sebidang tanah / bangunan yang ada, sehingga untuk itu perlulah tertib administrasi pertanahan dijadikan suatu hal yang wajar. (A.P. Parlindungan, 1999)

Pendaftaran hak dan pendaftaran peralihan hakatas tanah ini sebagai diatur dalam Pasal 19 ayat (2) sub b UUPA, merupakan sebagian dari tugas dan wewenang di bidang pendaftaran tanah. pendaftaran hak dan 
pendaftaran peralihan hak dapat dibedakan menjadi 2 tugas yaitu, pendaftaran hak atas tanah, dan pendaftaran peralihan hak atas tanah. (Chomzah, 2010)

Pendaftaran hak atas tanah adalah pendaftaran hak untuk pertama kalinya atau pembukuan suatu hak atas tanah dalam daftar buku tanah.Peralihan hak atas tanah adalah berpindahnya status kepemilikan hak atas tanah dari pihak yang satu sebagai pemberi hak, kepada pihak yang ke dua sebagai penerima hak.

Peralihan hak atas tanah bisa terjadi karena dua sebab, yaitu karena peristiwa hukum dan karena perbuatan hukum.Karena peristiwa hukum yaitu bahwa peralihan hak atas tanah terjadi dengan sendirinya, contoh peralihan hak atas tanah karena peristiwa hukum yaitu dengan terjadinya pewarisan. Sedangkan peralihan hak atas tanah yang terjadi karena perbuatan hukum yaitu bahwa peralihan hak atas tanah tersebut terjadi karena ada perbuuatan yang disengaja dari pemilik ha katas tanah tersebut untuk dialihkan hak nya kepada pihak lain. contoh dari peralihan hak atas tanah karena perbuatan hukum yaitu dapat berupa jual beli, tukar menukar, hibah, pemasukan dalam dalam modal perusahaan serta pemberian dengan wasiat dan lelang.

Peralihan hak atas tanah terbagi menjadi dua bentuk, Pertama beralih, yaitu berpindahnya hak atas tanah atau hak milik atas satuan rumah susun dari pemegang haknya kepada pihak lain karena pemegang hak nya meninggal dunia atau melalui pewarisan. Peralihan ini terjadi karena hukum, artinya dengan meninggalnya pemegang hak (subjek hak), maka ahli warisnya memperoleh hak atas tanah atau hak milik atas satuan rumah susun. Dalam beralih ini, pihak yang memperoleh hak harus memenuhi syarat sebagai pemegang (subjek) hak atas tanah atau hak milik atas satuan rumah susun. Kedua, dialihkan yaitu berpindahnya hak atas 
tanah atau hak milik atas satuan rumah susun dari pemegang (subjek) haknya kepada pihak lain karena suatu perbuatan hukum yang disengaja dilakukan dengan tujuan agar pihak lain tersebut memperoleh hak tersebut. (Santoso, 2012)

Jual beli tanah secara yuridis sebenarnya adalah mengenai jual beli hakatas tanahnya, tetapi secara umum orang banyak menyebut dengan istilah jual beli tanah. istilah jual beli sendiri dimuat dalam peraturan perundang - undangan yang berkaitan dengan pertanahan yaitu Undang - undang Nomor 5 Tahun 1960 tentang Peraturan Dasar Pokok - pokok Agraria atau banyak dikenal dengan UUPA. Dalam pasal 26 Undang undang Pokok Agraria menyebutkan bahwa, Jual beli, penukaran, penghibahan, pemberian dengan wasiat, pemberian menurut adat dan perbuatan perbuatan lain yang dimaksudkan untuk memindahkan hak milik serta pengawasannya diatur oleh peraturan pemerintah, dalam hal ini adalah peraturan pemerintah nomor 24 tahun 1997 tentang pendaftaran tanah.

Menurut Boedi Harsono, bahwa jual beli tanah adalah perbuatan hukum yang berupa penyerahan Hak Milik (penyerahan tanah untuk selama - lamanya) oleh penjual kepada pembeli, yang pada saat itu juga pembeli menyerahkan harganya kepada penjual. Jual beli yang mengakibatkan beralihnya hak milik atas tanah dari penjual kepada pembeli itu termasuk dalam hukum agraria atau hukum tanah. Objek dari peralihan hak atas tanah karena jual beli yaitu Hak milik sesuai dengan Pasal 20 ayat (2) UUPA bahwa hak milik bisa beralih dan dialihkan. Hak Guna Usaha sesuai dengan Pasal 16 ayat (2) huruf a PP. Nomor 40 Tahun 1996 tentang Hak Guna Usaha, Hak Guna Bangunan, dan Hak Pakai bahwa peralihan hak guna usaha terjadi dengan cara jual beli. Hak Guna Bangunan sesuai dengan Pasal 34 ayat (2) huruf a PP. Nomor 40 Tahun 
1996 bahwa peralihan hak guna usaha terjadi dengan cara jual beli, dan Hak Pakai sesuai dengan Pasal 43 UUPA yang menyebutkan bahwa "Sepanjang mengenai tanah yang dikuasai langsung oleh Negara maka hak pakai hanya dapat dialihkan kepada pihak lain dengan izin pejabat yang berwenang. Hak pakai atas tanah milik hanya dapat dialihkan kepada pihak lain, jika hal itu dimungkinkan dalam perjanjian yang bersangkutan. (Harsono, 2003)

\section{Pelaksanaan Pendaftaran Peralihan Hak Atas Tanah Karena Jual Beli} Menurut Peraturan Pemerintah Nomor 24 Tahun 1997

Prosedur pelaksanaan peralihan hak atas tanah karena jual beli terdapat syarat - syarat tertentu, yakni syarat materiil dan syarat formil. Syarat materil dalam peralihan hak karena jual beli diantaranya bahwa yang berhak melakukan perbuatan hukum jual beli atas tanah adalah orang yang namanya tercantum dalam sertipikat atau selain sertipikat (bilamana tanah tersebut belum didaftar). Kemudian seseorang yang berwenang menjual tanahnya adalah jika seorang tersebut sudah dewasa, jika belum dewasa maka perbuatan hukum jual beli ini bisa diwakili oleh walinya, atau bisa juga penjualnya diwakili oleh orang yang di berikan kuasa yang dibuktikan dengan menunjukan surat kuasa notariil.

Selain syarat materiil ada juga syarat formil yang harus dipenuhi dalam perbuatan hukum jual beli hak atas tanah. syarat formil yang dimaksud adalah bahwa setiap perbuatan hukum jual beli hak atas tanah harus dibuktikan dengan akta jual beli yang dibuat oleh dan dihadapan Pejabat Pembuat Akta Tanah (PPAT). Syarat jual beli yang mengharuskan pembuktiannya dengan akta PPAT diatur dalam Pasal 37 ayat (1) Peraturan Pemerintah No. 24 Tahun 1997, yang menyebutkan bahwa Peralihan hak atas dan Hak Milik Atas Satuan Rumah Susun melalui jual beli, tukar - menukar, hibah, pemasukan dalam perusahaan dan perbuatan 
hukum pemindahan hak lainnya, kecuali pemindahan hak melalui lelang hanya dapat didaftarkan jika dibuktikan dengan akta yang dibuat oleh PPAT yang berwenang menurut ketentuan peraturan perundang undangan yang berlaku. Pasal tersebut menjelaskan bahwa semua kegiatan peralihan hak atas tanah, kecuali lelang, maka harus dibuktikan dengan akta oleh PPAT.Tujuan dibuatnya akta dalam peralihan hak tersebut demi menjamin kepastian hukum para pihak, bahwa kegiatan peralihan hak tersebut benar - benar telah dilaksanakan dan juga sebagai dasar dalam pendaftaran peralihan hak nya kepada Kantor Pertanahan setempat.

Prosedur pelaksanaan pendaftaran peralihan hak atas tanah yaitu setelah PPAT membuat akta jual beli tersebut, maka PPAT wajib menyampaikan akta PPAT dan dokumen - dokumen lain yang diperlukan untuk keperluan pendaftaran pemindahan hak atas tanah atau Hak Milik Atas Satuan Rumah Susun yang bersangkutan kepada Kantor Pertanahan Kabupaten /Kota setempat, selambat - lambatnya tujuh hari kerja sejak ditandatanganinya akta yang bersangkutan. Dokumen - dokumen yang perlu diserahkan dalam pendaftaran peralihan hak kepada Kantor Pertanahan setempat adalah : (Santoso, 2012)

a. Surat permohonan pendaftaran Pemindahan hak yang di tandatangani oleh penerima hak (pembeli) atau kuasanya;

b. Surat kuasa tertulis dari pembeli, jika yang mengajukan permohonan pendaftaran Pemindahan hak bukan pembeli;

c. Akta jual beli oleh PPAT yang pada waktu pembuatan akta masih menjabat dan yang daerah kerjanya meliputi letak tanah yang bersangkutan;

d. Bukti identitas pihak yang mengalihkan hak (penjual);

e. Bukti identitas pihak yang menerima hak (pembeli); 
f. Sertipikat hak atas tanah asli yang dialihkan (diperjualbelikan);

g. Izin pemindahan hak bila diperlukan.

h. Bukti pelunasan Bea Perolehan Hak Atas Tanah dan Bangunan (BPHTB), dalam hal bea tersebut terutang; dan

i. Bukti pelunasan pembayaran pajak penghasilan $\mathrm{PPh}$, dalam hal pajak tersebut terutang.

Setelah dokumen - dokumen tersebut disampaikan oleh PPAT kepada Kantor Pertanahan setempat, maka Kantor Pertanahan tersebut akan memproses dengan melakukan pencatatan pemindahan hak dalam buku tanah, sertipikat, dan daftar lainnya.

\section{Simpulan}

Salah satu tujuan dari perndaftaran tanah adalah untuk memberikan kepastian hukum bagi pemilik hak atas tanah sendiri. Kepastian hukum dalam pendaftaran tanah pertama kali maupun untuk pemeliharaan data pendaftaran tanah tersebut. Sehingga dalam setiap perbuatan hokum mengenai hak atas tanah di haruskan untuk dilakukan pendaftaran kepada Kantor Pertanahan setempat.

Prosedur pelaksanaan peralihan hak atas tanah karena jual beli, baik pelaksanaan jual beli dan pendaftarannya menurut Peraturan Pemerintah Nomor 24 Tahun 1997 sudah sangat jelas, bahwa dalam peralihan hak atas harus didasari oleh akta yang dibuat oleh PPAT. Akta PPAT merupakan syarat formil dalam salah satu dokumen yang digunakan sebagai syarat pendaftaran peralihan hak atas tanah. Dengan didaftarkan nya seluruh kegiatan dalam hal perbuatan hukum mengenai peralihan hak atas tanah, maka akan terciptanya tertib administrasi pertanahan.

Tertib administrasi pertanahan menjadi salah satu faktor untuk mengurangi tingkat perselisihan mengenai kepemilikan hak atas tanah, sehingga kedepan diharapkan tidak ada lagi masalah - masalah dalam 
pertanahan baik mengenai sengketa tanah maupun ketidakjelasan status kepemilikan hak atas tanah.

\section{Daftar Pustaka}

A.P. Parlindungan. (1999). Pendaftaran Tanah Di Indonesia (berdasarkan PP No.24 Tahun 1997) (Vol. 2). Bandung: Mandar Maju.

Chomzah, A. A. (2010). Hukum Agraria (Pertanahan Indonesia) Jilid 2. Jakarta: Prestasi Pustaka.

Harsono, B. (2003). Hukum Agraria Indonesia Sejarah Pembentukan Undang - undang Pokok Agraria, Isi, dan Pelaksanaannya. Jakarta: Djambatan.

Marhel, J. (2017). Proses Pendaftaran Peralihan Hak Atas Tanah Dalam Perspektif Kepastian Hukum. Masalah Masalah Hukum, 249-256. doi:https://doi.org/10.14710/mmh.46.3.2017.249-256

Pratama, E. A. (2020). Business Ethics And Legal Liability In The Management Of State-Owned Enterprises. Journal Critical od Law, 1401-407. Retrieved from http://www.jcreview.com/?mno=22413

Rachmawati, I. N. (2007, Maret ). Pengumpulan data dalam penelitian kualitatif : Wawancara,. Jurnal Keperawatan Indonesia, 11, 35-40.

Santoso, C. M. (2015). PENDAFTARAN PERALIHAN HAK ATAS TANAH KARENA JUAL-BELI DI KOTAMADYA DAERAH TINGKAT II SEMARANG. Semarang: Prodi Ilmu Hukum UNIKA Soegijapranata. Retrieved from http://repository.unika.ac.id/4635/

Santoso, U. (2012). Pendaftaran dan Peralihan Hak atas Tanah. Jakarta: Kencana. 